\title{
The Effect of Priming Treatments on Germination and Seedling Performance of Purslane (Portulaca oleracea) Seed Lots
}

\author{
Eren OZDEN* and Ibrahim DEMIR \\ Department of Horticulture, Faculty of Agriculture, Ankara University, 06110-Diskapi, Ankara, Turkey \\ *Corresponding author, e-mail: erozden@ankara.edu.tr
}

Bulletin UASVM Horticulture 74(2)/ 2017

Print ISSN 1843-5254, Electronic ISSN 1843-5394

DOI:10.15835/buasvmcn-hort: 0032

\begin{abstract}
This study was conducted to test the effect of a priming combination on the seed germination percentage and seedling emergence performance of purslane under climate chamber and field conditions. Four purslane seed lots were treated according five different methods, which were T1: Seeds kept at a hundred percent relative humidity for four hours at $20^{\circ} \mathrm{C}$; T2: Seeds kept at a hundred percent relative humidity for four hours at $20^{\circ} \mathrm{C}$, and then soaked in distilled water for 8 hours at $5^{\circ} \mathrm{C}$; T3: Seeds kept at a hundred percent relative humidity for four hours at $20^{\circ} \mathrm{C}$, and then soaked in distilled water for 8 hours at $20^{\circ} \mathrm{C}$; T4: Seeds soaked in distilled water for 8 hours at $5{ }^{\circ} \mathrm{C}$; T5: Seeds soaked in distilled water for 8 hours at $20^{\circ} \mathrm{C}$; and C: Control (untreated). Seed germination was calculated for 14 days at $20^{\circ} \mathrm{C}$, seedling emergence percentages were calculated in the climatically-controlled chamber for 21 days at $22^{\circ} \mathrm{C}$, and in the field for 35 days at $15-25^{\circ} \mathrm{C}$. The highest seed germination $(94 \%)$ and seedling emergence in the climatically-controlled chamber (87\%) and field (82\%) were obtained from seeds that had been kept at a hundred percent relative humidity for four hours at $20^{\circ} \mathrm{C}$, then soaked in distilled water for eight hours at $5^{\circ} \mathrm{C}$. Results indicated that farm-priming, can be an efficient priming method in purslane seeds.
\end{abstract}

Keywords: farm-priming, germination, seedling emergence, seedling fresh weight, soaked seed

\section{INTRODUCTION}

Purslane is a leafy vegetable that can be consumed both raw (in salad) or cooked. Among vegetables, it is particularly notable for its high omega-3 content. Purslane is cultivated by direct sowing in the field. In leafy vegetables such as purslane, irregular germination and emergence can be a cause of low yield due to late germinaters and ungerminated seeds. Late germinators are characterised by smaller leaf and plant size. In various crop seeds, fast germination was reported to be the main reason behind larger plant size (Mavi et al., 2010). Therefore, faster germination in the field can be an effective approach to obtain higher purslane yield. A simple and practical method for ensuring this is priming, which involves the imbibition of seeds to induce metabolic activities, before sowing into the field (Bennett et al., 1992).
This method used in developing countries is called farm priming, in which seeds are soaked in the water typically for about 8 hours overnight, and then surface dried and sown in following day (Harris et al., 2001). This has been proven to be a beneficial method to obtain higher stand establishment in agronomical crops, such as rice, chickpea and maize, in the developing parts of the World (Harris et al., 1999). It is mainly produced at a local level for local consumption. This study was conducted to test whether pre-soaking humidification before farm priming (soaking) may have a positive effect on germination and emergence in both climate chamber and field conditions. The aim of this study was to develop a simple method for farmers to obtain better stand establishment with purslane. 
Tab. 1. Changes in germination percentages of four purslane seed lots after priming treatments

Seed Lot

\begin{tabular}{cccccc}
\hline Treatment & 1 & 2 & 3 & 4 & Mean \\
\hline T1 & $90 \pm 0.71 \mathrm{a}$ & $91 \pm 0.71 \mathrm{~b}$ & $92 \pm 0.41 \mathrm{~b}$ & $96 \pm 1.41 \mathrm{ab}$ & $92 \pm 1.32$ \\
\hline $\mathrm{T} 2$ & $90 \pm 0.41 \mathrm{a}$ & $93 \pm 0.41 \mathrm{a}$ & $94 \pm 0.00 \mathrm{a}$ & $97 \pm 0.41 \mathrm{a}$ & $94 \pm 1.44$ \\
\hline $\mathrm{T} 3$ & $86 \pm 0.71 \mathrm{~b}$ & $90 \pm 1.08 \mathrm{~b}$ & $90 \pm 0.71 \mathrm{c}$ & $95 \pm 0.71 \mathrm{~b}$ & $90 \pm 1.84$ \\
\hline $\mathrm{T} 4$ & $83 \pm 1.08 \mathrm{c}$ & $88 \pm 1.41 \mathrm{c}$ & $89 \pm 0.71 \mathrm{c}$ & $93 \pm 0.71 \mathrm{c}$ & $88 \pm 2.06$ \\
\hline $\mathrm{T} 5$ & $78 \pm 0.41 \mathrm{~d}$ & $85 \pm 1.47 \mathrm{~d}$ & $87 \pm 1.08 \mathrm{~d}$ & $91 \pm 0.91 \mathrm{~d}$ & $85 \pm 2.72$ \\
\hline $\mathrm{C}$ & $74 \pm 1.47 \mathrm{e}$ & $79 \pm 2.48 \mathrm{e}$ & $80 \pm 2.12 \mathrm{e}$ & $85 \pm 1.78 \mathrm{e}$ & $80 \pm 2.26$ \\
\hline \multicolumn{7}{l}{ Note: Mean values with the differentletters in the same column are different at 5\%. }
\end{tabular}

\section{MATERIAL AND METHODS}

Four purslane seed lots (Portulaca oleracea cv. Yeşil) were obtained from seed suppliers in Ankara. Seeds were kept in hermetic (air and waterproof) packets. Seed moisture content was measured at $130{ }^{\circ} \mathrm{C}$ for 1 hour, and was found to be $10.77 \%$ and $11.75 \%$. Seeds were treated in five different ways. These treatment methods were T1: Seeds kept at a hundred percent relative humidity for four hours at $20^{\circ} \mathrm{C}$; T2: Seeds kept at a hundred percent relative humidity for four hours at $20^{\circ} \mathrm{C}$, and then soaked in distilled for 8 hours at $5{ }^{\circ} \mathrm{C}$; T3: Seeds kept at a hundred percent relative humidity for four hours at $20^{\circ} \mathrm{C}$, and then soaked in distilled for 8 hours at $20^{\circ} \mathrm{C}$; T4: Seeds soaked in distilled for 8 hours at $5{ }^{\circ} \mathrm{C}$; T5: Seeds soaked in distilled for 8 hours at $20^{\circ} \mathrm{C}$; and C: Controls (untreated seeds).

Following these treatments, the seeds were surface dried for about 30 minutes, after which germination tests and sowing in field and climatic chambers were performed. Germination tests were carried out on four replicates of 50 seeds, according to ISTA (ISTA, 2012). The germination test was continued for 14 days, and normal seedling percentages were determined and expressed in terms of percentage. Field sowing was performed on a sandy loamy soil, with four replicates of 50 seeds at $2 \mathrm{~cm}$ deep. Seeds were considered emerged when the cotyledons appeared on the surface. Counts were performed for 35 days, and final emergence percentages were calculated. Sowings in climatically-controlled chamber was performed in peat moss and perlite mixture (2:1), with 50 seeds of 4 replicates. Emergence percentages were calculated after 21 days at $20^{\circ} \mathrm{C}$, with $72 \mu \mathrm{Mol} \mathrm{m}^{-2} \mathrm{~s}^{-1}$ of enlightenment. Appearance of cotyledons on the surface was used as emergence criterion in both sowing environment. After final counts (35 days), the aerial parts of the 20 seedlings ( 4 replicates $x$ seedlings) were cut and weighed. Seedling fresh weight was calculated for each plant as $\mathrm{g} /$ plant. Statistical analyses were carried out using the SPSS by ANOVA multiple range test (DUNCAN), and the differences between means were expressed at $5 \%$ level.

\section{RESULTS AND DISCUSSION}

The lowest germination percentages were observed in the control seeds. The mean germination percentages of the four lots for control seeds were found to be $80 \%$, while the highest germination was observed in T2 as $94 \%$ (Tab. 1).

The other types of treatments resulted in germination percentages between these two values. A number of significant differences were observed between the lots. T1 and T2 were significantly different compared to the other treatments $(\mathrm{p}<0.05)$. T2 had $87 \%$ emergence in the climatically-controlled chamber, and $82 \%$ in the field conditions (Tab. 2), while control seeds had $73 \%$ and $68 \%$ emergence in climate chamber and field conditions, respectively. The advantage in emergence for T2 compared with the control was between $13 \%$ and $17 \%$ under climaticallycontrolled chamber conditions, and $10 \%$ and $19 \%$ in the field emergence trials (Tab. 2). When the mean of all the four lots were analysed, the difference between $\mathrm{T} 2$ and the control seeds was found to be $14 \%$ in the emergence trials.

$\mathrm{T} 2$ produced double-sized seedlings as compared to control. The mean T2 seedling fresh weight between the four lots was $5.57 \mathrm{mg} /$ plant, while the same mean value for the control seeds was $2.33 \mathrm{mg} /$ plant (Tab. 3). The rest of the 
Tab. 2. The effect of priming on seedling emergence percentages in four purslane seed lots under climatically-controlled chamber and field conditions

\begin{tabular}{|c|c|c|c|c|c|c|}
\hline \multicolumn{7}{|c|}{ Seed Lot } \\
\hline & Treatment & 1 & 2 & 3 & 4 & Mean \\
\hline \multirow{6}{*}{ 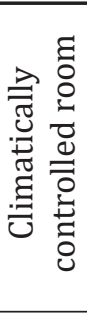 } & $\mathrm{T} 1$ & $83 \pm 1.08 \mathrm{a}$ & $85 \pm 0.41 \mathrm{~b}$ & $84 \pm 1.08 \mathrm{a}$ & $90 \pm 0.41 \mathrm{~b}$ & $86 \pm 1.56$ \\
\hline & $\mathrm{T} 2$ & $84 \pm 0.41 \mathrm{a}$ & $87 \pm 0.00 \mathrm{a}$ & $83 \pm 1.08 \mathrm{a}$ & $92 \pm 0.41 \mathrm{a}$ & $87 \pm 2.02$ \\
\hline & T3 & $80 \pm 1.47 \mathrm{~b}$ & $83 \pm 1.08 \mathrm{c}$ & $77 \pm 0.82 \mathrm{~b}$ & $88 \pm 1.41 \mathrm{c}$ & $82 \pm 2.35$ \\
\hline & $\mathrm{T} 4$ & $78 \pm 0.41 \mathrm{c}$ & $80 \pm 1.41 \mathrm{~d}$ & $78 \pm 0.71 b$ & $84 \pm 1.08 \mathrm{~d}$ & $80 \pm 1.41$ \\
\hline & T5 & $76 \pm 0.41 \mathrm{~d}$ & $80 \pm 1.78 \mathrm{~d}$ & $75 \pm 0.82 \mathrm{c}$ & $83 \pm 0.71 \mathrm{~d}$ & $79 \pm 1.85$ \\
\hline & $\mathrm{C}$ & $67 \pm 1.78 \mathrm{e}$ & $73 \pm 2.12 \mathrm{e}$ & $70 \pm 1.08 \mathrm{~d}$ & $80 \pm 0.41 \mathrm{e}$ & $73 \pm 2.78$ \\
\hline \multirow{6}{*}{ 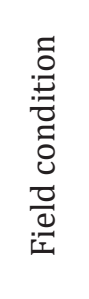 } & $\mathrm{T} 1$ & $81 \pm 0.41 \mathrm{a}$ & $75 \pm 0.41 \mathrm{~b}$ & $80 \pm 0.41 \mathrm{~b}$ & $85 \pm 0.41 \mathrm{~b}$ & $80 \pm 2.06$ \\
\hline & $\mathrm{T} 2$ & $82 \pm 0.41 \mathrm{a}$ & $77 \pm 0.41 \mathrm{a}$ & $82 \pm 0.00 \mathrm{a}$ & $88 \pm 0.41 \mathrm{a}$ & $82 \pm 2.25$ \\
\hline & T3 & $74 \pm 0.71 \mathrm{~b}$ & $72 \pm 0.71 \mathrm{c}$ & $78 \pm 0.41 \mathrm{c}$ & $80 \pm 0.71 \mathrm{c}$ & $76 \pm 1.83$ \\
\hline & $\mathrm{T} 4$ & $73 \pm 0.41 \mathrm{~b}$ & $69 \pm 0.41 \mathrm{~d}$ & $75 \pm 0.71 \mathrm{~d}$ & $79 \pm 0.41 \mathrm{c}$ & $74 \pm 2.08$ \\
\hline & T5 & $71 \pm 0.41 \mathrm{c}$ & $70 \pm 0.41 \mathrm{~d}$ & $74 \pm 0.41 \mathrm{~d}$ & $76 \pm 0.41 \mathrm{~d}$ & $73 \pm 1.38$ \\
\hline & $\mathrm{C}$ & $63 \pm 1.78 \mathrm{~d}$ & $67 \pm 0.71 \mathrm{e}$ & $68 \pm 1.08 \mathrm{e}$ & $74 \pm 0.71 \mathrm{e}$ & $68 \pm 2.27$ \\
\hline
\end{tabular}

Note: The lowercase letters denote significant differences between the treatments applied for the same lot (5\%).

Tab. 3. The effect of priming treatments on seedling fresh weight $(\mathrm{g} / \mathrm{plant})$, obtained from field conditions after 35 days of sowing

Seed Lot

\begin{tabular}{cccccc}
\hline Treatment & 1 & 2 & 3 & 4 & Mean \\
\hline T1 & $2.48 \pm 0.07 \mathrm{~b}$ & $4.34 \pm 0.07 \mathrm{a}$ & $6.96 \pm 0.11 \mathrm{~b}$ & $7.86 \pm 0.07 \mathrm{a}$ & $5.41 \pm 1.23$ \\
\hline T2 & $2.83 \pm 0.11 \mathrm{a}$ & $4.21 \pm 0.07 \mathrm{a}$ & $7.32 \pm 0.07 \mathrm{a}$ & $7.92 \pm 0.14 \mathrm{a}$ & $5.57 \pm 1.22$ \\
\hline $\mathrm{T} 3$ & $1.76 \pm 0.14 \mathrm{c}$ & $2.83 \pm 0.08 \mathrm{c}$ & $5.18 \pm 0.14 \mathrm{c}$ & $5.69 \pm 0.18 \mathrm{~b}$ & $3.87 \pm 0.94$ \\
\hline T4 & $1.64 \pm 0.09 \mathrm{c}$ & $3.13 \pm 0.10 \mathrm{~b}$ & $4.86 \pm 0.11 \mathrm{~d}$ & $5.62 \pm 0.14 \mathrm{~b}$ & $3.81 \pm 0.89$ \\
\hline T5 & $1.73 \pm 0.11 \mathrm{c}$ & $2.34 \pm 0.11 \mathrm{~d}$ & $4.04 \pm 0.07 \mathrm{e}$ & $4.14 \pm 0.21 \mathrm{c}$ & $3.06 \pm 0.61$ \\
\hline $\mathrm{C}$ & $0.84 \pm 0.18 \mathrm{~d}$ & $1.93 \pm 0.20 \mathrm{e}$ & $3.13 \pm 0.21 \mathrm{f}$ & $3.43 \pm 0.29 \mathrm{~d}$ & $2.33 \pm 0.59$ \\
\hline
\end{tabular}

treatments had values in-between these two. All treated seeds had higher seedling fresh weight values than the control.

The results obtained were in agreement with the findings of other studies on various agronomical crop seeds that show farm priming to be an effective treatment for rapid and successful stand establishment (Harris et al., 2001; Harris and Mottam, 2005). Harris et al., (1999) described that farm priming can bea cheap and practical treatment for the poorer parts of the world. However, keeping seeds at high humidity (humidification) before soaking instead of straight soaking into the water accelerated the effectiveness of farm priming. Humidification before soaking increased seed emergence 6 to $9 \%$ compared to straight soaked seeds without humidification (Compared T2 and $\mathrm{T} 3$ with T4 and T5). Humidification without soaking was also beneficial in comparison with straight soaking, but humidification plus soaking considerably enhanced the effectiveness of the treatment. The reason might be associated with the prevention of soaking injury, which occurs during the straight soaking seed with low moisture content, as is particularly observed with legume seeds (Legesse and Powell, 1992). Seed moisture content was increased to about 19-21\% when humidification was performed before soaking, while non-humidified seeds' moisture contents remained at about $10-11 \%$. At the end of the soaking treatment, seed moisture was found to be above 33\%. Therefore, as reported for legumes, a slight increase in seed moisture may be beneficial for obtaining maximum benefit from priming (Powell et al., 1984). 


\section{CONCLUSION}

The simple and practical treatment known as farm priming can be effectively used in combination with humidification to increase seed moisture content to about $20 \%$ before soaking. The higher emergence and better stand establishment resulting from this method can be used to the benefit of low income farmers.

\section{REFERENCES}

1. Bennett MA, Fritz VA and Callan NW (1992). Impact of seed treatments on crops stand establishment. HortTechnology, 2: 345-349.

2. Harris D and Mottam A (2005). Practical hydration of seeds of tropical crops: 'on-farm priming' seed priming. In Hand book of seed Science and Technology' AS Basra Ed. (pp. 724-734), The Howarth Press, New York.

3. Harris D, Joshi A, Khan PA, Gothkar P and Sodhi PS (1999). On-farm seed priming in semi-arid agriculture:
Development and evaluation in maize, rice, and chickpea in India using participitary methods. Experimental Agriculture, 35: 15-29.

4. Harris D, Pathan AK, Gothkar P, Joshi A, Chivasa W and Nyamudeza $P$ (2001). On-farm seed priming: Using participitary methods to revive and refine a key technology. Agricultural Systems, 69 (1-2): 151-164.

5. ISTA (2012). International Rules for Seed Testing, International Seed Testing Association, Bassersdorf, Switzerland.

6. Legesse N and Powell AA (1992). Comparison of water uptake and imbibition damage in eleven cowpea cultivars. Seed Science and Technology, 20: 173-180.

7. Mavi K, Demir I and Matthews S (2010). Mean germination time estimates the relative emergence of seed lots of three cucurbit crops under stress conditions. Seed Science and Technology, 38: 14-25.

8. Powell AA, Matthews S and Oliveira M de A (1984). Seed quality in grain legumes. Advances in Applied Biology, 10: 217-285. 